\title{
A légszennyezés egészségkárosító hatásának közismertsége Magyarország észak-keleti részén
}

\author{
Public awareness of air pollution and health threats in the \\ North-Eastern region of Hungary
}

Szerzők: Juhászné Szalai Adrienn $₫$ $₫$, Dr. Kiss-Tóth Emőke ${ }^{b}$
a: Miskolci Egyetem, Egészségügyi Kar, Egészségfejlesztési Módszertani Intézet, Miskolc,
b: Miskolci Egyetem, Egészségügyi Kar, Alkalmazott Egészségtudományok Intézete, Miskolc

Beküldve: 2019. 10. 21.

doi: $\quad$ 10.24365/ef.v61i1.526

\begin{abstract}
Összefoglaló:
Bevezetés: A tanulmány célja, hogy képet kapjunk a lakosság ismereteiről a levegőszenynyezés hatására kialakuló egészségkárosodás kapcsán. A levegőszennyezés egyre nagyobb problémát jelent már Magyarországon is, ezért vizsgáltuk azt, hogy a lakosság milyen ismeretekkel rendelkezik a témában, és mennyire gondolja komoly veszélynek a levegőszennyezést.
\end{abstract}

Módszertan: Kérdőíves formában vizsgáltuk, hogy milyen ismeretekkel rendelkeznek az észak-magyarországi régióban, elsősorban Miskolc környékén élő emberek a légkör szennyező anyagairól és azok egészségre gyakorolt hatásáról. Túlnyomóan többszörös választást megengedő zárt vagy vegyes kérdéseket alkalmaztunk. A válaszadás önkéntes alapon történt egy közösségi oldal segítségével, és összesen 153 fő töltötte ki teljes mértékben a kérdőívet. A válaszadók életkora 18 és 56 év közé esett, de a legtöbb válaszadó 25 év alatti volt.

Eredmények: Az elvégzett felmérés alapján az emberek többsége tisztában van a levegőszennyező tényezőkkel és azok esetleges káros hatásával, azonban az, hogy az egyes légköri szennyezők milyen konkrét kockázatot jelenthetnek az emberi egészségre, nem minden esetben ismert.

Következtetés: Az eredmények azt mutatják, hogy a válaszadók ismeretei elég sokrétúek, és ismerik a lehetséges veszélyeket és megoldási lehetőségeket. Mindezek ellenére hasznos lenne ismeretterjesztő előadássorozat a témát érintően, amely segítheti a meglévő ismeretek pontosítását, és ösztönözheti az embereket, hogy egyénileg tegyenek meg minél többet a levegő minőségének javításáért.

Kulcsszavak: levegőszennyezés; egészségtudatosság; egészségkárosító hatás

\section{Summary:}

Introduction: The purpose of this study is to gain an understanding of the population's awareness of health damage caused by air pollution. Air pollution is already a growing problem in Hungary, thus we studied what the public knows about the topic and how much the public considers air pollution to be a serious threat.

Methodology: A questionnaire was used to survey people's awareness of atmospheric pollutants and their effects on health living in the region of Northern Hungary especially around Miskolc. Multiple-choice closed or mixed questions were mostly used. The selection was made on a voluntary basis with the help of a social network site and a total 
of 153 persons filled in the questionnaire. The age of responders ranged from 18 to 55, but most of them were under 25.

Results: According to the survey, most people are aware of air pollution factors and their potentially harmful effects, but the specific risk to human health of each air pollutant is not always known.

Conclusion: The results show that respondents have a fairly wide range of knowledge and their knowledge about potential hazards and possible solutions. Nevertheless, it would be useful to have a series of educational lectures on the topic that can help refine existing knowledge and encourage people to do their best to improve air quality individually.

Keywords: air pollution; health awareness; adverse health effect

\section{BEVEZETÉS}

Önálló életünk az első légvétellel kezdődik, és halálunk napjáig ezt percenként 12-16-szor megismételjük nyugodt körülmények között. Testünk sejtjeinek megfelelő múködéséhez alapvető fontosságú a légzés segítségével lezajló gázcsere, amihez megfelelő nagyságú tüdőfelületre, valamint tiszta levegőre van szükség.

A légkör természetes összetétele is sokféle gáznemű és szilárd anyagot tartalmaz, de a természetes forrásokhoz adódó emberi tevékenységből származó, azaz antropogén eredetű kibocsátás nagyban megváltoztatta az összetevők arányát, olyan mértékben, hogy az már károsan hat környezetre, és ennek következtében az emberi egészségre is. Ebben az esetben már levegőszennyezésről beszélünk. ${ }^{1,2}$

Napjainkban a levegő szennyezése, akár a lakóépületeken belül is, olyan mértéket ölt, amely számos megbetegedést vált ki, illetve idő előtti halálesetekért tehető felelőssé. ${ }^{3,4}$ A World Health Organization (WHO) adatai alapján 2016-ban a világ lakosságának több mint 90\%-a élt olyan területeken, amelyek a levegő minőségére vonatkozó irányelveknek nem feleltek meg. ${ }^{4} \mathrm{~A}$ WHO adatai szerint ugyanebben az évben világszerte 4,2 millió idő előtti haláleset következett be a szennyezett levegő miatt, és az 5 év alatti gyermekek közel fele halt meg tüdőgyulladásban. ${ }^{4}$ Ezekért a halálesetekért fóként a légkör szállóportartalmának (particulate matter: PM) a nagyon finom tartománya, a 2,5 $\mu \mathrm{m}$ vagy annál kisebb átmérővel rendelkező részecskéket tartalmazó része $\left(\mathrm{PM}_{2,5}\right)$ tehető felelőssé. A nagyon finom tartományt alkotó porrészecskék akár az alveolusok hámján is átjutnak, így a keringési rendszerbe kerülnek, ezáltal számos szervben okozhatnak elváltozásokat. ${ }^{2,4,5}$ A PM egészségre gyakorolt hatását számos kutatócsoport vizsgálja világszerte. Szoros összefüggést találtak a levegő magas szállóportartalma és bizonyos betegségek fokozott megjelenése vagy az ezekben a betegségekben szenvedő betegek állapotromlása között. Elsősorban - az inhalatív úton bejutásnak köszönhetően a légúti megbetegedések és fertőzések száma növekedett, különösen gyermekkorban, illetve a már asztmával vagy egyéb krónikus megbetegedéssel küzdő embereknél és gyermekeknél állapotromlást tapasztaltak. ${ }^{4,5}$ Számos esetben kimutatták, hogy mind a $10 \mu \mathrm{m}$ átmérőjū része a szállóportartalomnak $\left(\mathrm{PM}_{10}\right)$, mind a $\mathrm{PM}_{2,5}$-tartománya már néhány nap rendszeres expozíció után eltéréseket okoz a perifériás vérben mérhető paraméterekben. A PM 2,5 hatását vizsgálva Riediker és munkatársai azt tapasztalták, hogy az expozíciónak kitett emberek csoportjánál emelkedett a vérben a különböző gyulladásra utaló faktorok értéke, mint például a C-reaktív protein szintje és a neutrofil granulociták aránya, míg a limfociták aránya csökkent, ami szintén gyulladás kialakulására utal. Mindeközben a véralvadási rendszernél azt találták, hogy a von Willebrand faktor szintje is növekedett, ami serkentheti a trombociták aggregációját, ez pedig fokozhatja az ereken belüli vérrögképződés valószínűségét. ${ }^{6,7} \mathrm{~A} \mathrm{PM}_{10}$-tartomány vizsgálatakor számos, az immunrendszer működését segítő, a fehérvérsejtek közötti kapcsolatokat szabályozó interleukin (IL) szintjének változását mérték a perifériális vérből. Azt tapasztalták, hogy pl. az IL-6 szintje emelkedést mutatott a vizsgálat során, ami növelheti a miokar- 
diális infarktus kialakulásának esélyét, emellett a gyulladásos folyamatokban serkentő szerepet játszó tumor nekrózis faktor alfa (TNF- $\alpha$ ) szintjének emelkedését is tapasztalták. ${ }^{8}$

Mindezek mellett a szállópor részecskéi tehetők felelőssé számos kardiovaszkuláris megbetegedés előfordulásának a növekedéséért is. A részecskék térfogatához viszonyított felszíne jelentős, így képesek jelentős mennyiségű anyagot megkötni, majd a szervezetbe juttatni. Ezek közül a felületen megkötött anyagok közül a fémek hordozzák a legnagyobb egészségügyi kockázatot. ${ }^{1}$ Uzu és munkatársai a felületükön ólmot megkötő PM-részecskék hatását vizsgálták, és a gyulladásos citokinek szintjének emelkedését tapasztalták, amelyek pozitív korrelációt mutattak az ólom koncentrációjának emelkedésével. ${ }^{9}$ Ezek a vizsgálatok egyértelműen alátámasztják, hogy a szállópor minden frakciója aktívan részt vesz a gyulladásos folyamatok indukálásában.

A légkörben nemcsak a szilárd fázisú részecskék aránya növekedett, hanem a gázfázisú anyagoké is. Az emberi tevékenység hatására elsősorban a széndioxid $\left(\mathrm{CO}_{2}\right)$ és a metán $\left(\mathrm{CH}_{4}\right)$ koncentrációja emelkedett meg, amelyek - az üvegházhatás fokozása miatt - aktív tényezői a globális felmelegedésnek. ${ }^{10,11,12}$ Ezáltal közvetett egészségügyi kockázatot jelentenek az egészségünkre, mivel a meleg okozta mortalitás világszerte növekszik, és már Európában is érezhető a hatása. ${ }^{13,14} \mathrm{~A}$ benzin- és gázolajüzemű gépjárművek nagymértékű elterjedése miatt nitrogén-oxidok $\left(\mathrm{NO}_{\mathrm{x}}\right)$ és a kén-dioxid $\left(\mathrm{SO}_{2}\right)$ mennyiségének növekedése is jelentős. Ezek a gázok komoly közvetlen egészségügyi kockázatot jelentenek, mivel belélegzésük fokozhatja a bronchitises tüneteket főleg gyermekeknél, rontja a légzésfunkciót, tüdőgyulladást, köhögést, és a nyáktermelés fokozódását válthatja ki. ${ }^{4} \quad$ Közvetve viszont szintén hozzájárulnak a klíma hőmérsékletének változásához és a savas esők kialakulásához, ezáltal áttételesen hatva az emberek egészségére. Egészségkárosító hatásukat olyan módon fejtik ki, hogy megváltoztatják mind talaj, mind a vizek $\mathrm{pH}$-ját, ezáltal kedvezőtlenül hatnak a természetes élővilágra, a mezőgazdasági termelésre és az élelmiszerek minőségére egyaránt. ${ }^{15} \mathrm{~A} \mathrm{NO}_{\mathrm{x}}-\mathrm{k}$ és erős UV sugárzás hatására a légkör alacsonyabb régióiban is megjelenik az ózonmolekula $\left(\mathrm{O}_{3}\right)$, amely aktív résztvevője a - főleg nyáron egyre gyakrabban kialakuló - fotokémai szmognak. ${ }^{16}$ Belélegzése szintén légzési nehézségekhez, tüdőbetegségek kialakulásához vezethet. ${ }^{4}$

A téma jelentőségét az is mutatja, hogy 2018. november 1-én a WHO szervezésében megtartották az első, légszennyezésről szóló globális konferenciát "Tiszta levegőt az egészségért" címmel, ahol célul tűzték ki 2030-ra a levegő szennyezéséből eredő halálesetek számának 2/3-dal csökkentését. Emellett kiemelt szerepet kapott a gyerekek védelme, főleg azokban a régiókban, ahol már születésüktől fogva fokozott expozíciónak vannak kitéve. Jelenleg 10 gyerekből 9 nem „biztonságos” levegőt lélegez be. ${ }^{17} \mathrm{~A}$ légszennyezők hatása még az anyaméhben fejlődő magzatokra is hatással lehet, főleg ha nehézfémtartalommal szennyezett részecskék kerülnek az anya szervezetébe, mert ezek megnövelik mind a spontán abortuszok, mind a fejlődési rendellenességek számát. ${ }^{1}$ Mivel az urbanizáció világjelenség, ezért a fenti problémák egyre több embert érintenek, sokszor már születésüktől fogva, így egyre hamarabb jelennek meg a levegőszennyezés hatásának tulajdonítható különböző megbetegedések. A megoldás részben az egyének kezében, részben pedig a törvényhozáséban van, mivel a légkör szenynyezéséhez nagyban hozzájárul az erőművek, de a háztartások károsanyag-kibocsátása is. Tanulmányok születnek arra vonatkozóan, milyen városvezetési intézkedések lennének szükségesek ahhoz, hogy a városi emberek egészségesebb levegőt lélegezhessenek be. ${ }^{18}$ Lehetséges megoldásnak tünik a szennyezők kibocsátásának csökkentése mellett egy új keletű technológia is, az ún. élő vagy zöld falak kialakítása, amelyekkel az épületek, a felhőkarcolók külső felületét és a belső tereit is összefüggő növénytakaróval borítják be. Ez a megoldás segíti az épület és környezetének hútését amellett, hogy részt vesz a levegő minőségének javításában is, mivel felfogja a szilárd szennyeződéseket, és oxigént termel, valamint szabályozza az esővíz elfolyását. ${ }^{19}$ Erre vonatkozó kezdeményezéseket már Magyarországon is találunk, bár egyelőre a beltéri alkalmazás még gyakoribb. Található beltéri zöldfal a Corvinus Egyetem alulájában, vagy például a budapesti Green House és Eiffel Palace irodaházakban, ahol nemcsak a látványával javítja közérzetet, hanem részt vesz a levegő minőségének javításában is az adott beltérben. ${ }^{20}$ Kültéri zöldfalként múködhet az a bárki által elérhető megoldás, amikor 
például vadszőlővel vagy más kúszónövénnyel futtatjuk be a házfalakat.

Jelen vizsgálatban azt terveztük felmérni, hogy az észak-magyarországi régióban, elsősorban Miskolcon és annak környékén élő emberek milyen ismeretekkel rendelkeznek a légkörről, annak természetes összetevőiről és az esetleges szennyezők egészségre káros hatásáról. Ennek vizsgálatára leginkább a téli időszakban az ország ezen területén gyakran megjelenő kiugróan magas légszennyezési adatok adnak alapot. ${ }^{21} \mathrm{Az}$ értékek objektív mérése mellett fontos a területen élők véleménye. A háztartások lakói is, ha elegendő információval rendelkeznek a témában, sokat tehetnek a légszennyezés csökkentése érdekében, ezáltal megőrizve saját egészségüket. Ezt támasztja alá az a 2019-ben elvégzett európai uniós közvéleménykutatás, amely több európai országban, köztük Magyarországon felmérte a lakosság véleményét a levegő minőségére vonatkozóan. ${ }^{22}$ Ebben a kutatásban részt vevő magyar emberek (1010 fő) 52\%-a a témában nem vagy nem jól informáltnak tartotta magát, ami alátámasztja kérdőívünk fontosságát. A hazai és nemzetközi vizsgálatok célcsoportjai elsősorban az általános vagy középiskolák diákjai, nem pedig a felnőtt korosztály, akik viszont sokat tehetnek egyénként is azért, hogy közvetlen környezetükben jobb legyen a levegő minősége. ${ }^{23,24,25,26,27}$

\section{MÓDSZERTAN}

Mindezek tükrében szerettük volna felmérni, hogy a régiónkban élők mennyire tartják problémásnak közvetlen környezetük levegőjének tisztaságát. Annak eldöntésére, hogy az emberek mennyire vannak tisztában a légszennyezés egészségügyi hatásaival, kérdőíves információgyújtést alkalmaztunk. A kérdőív elkészítésekor olyan saját szerkesztésú kérdéseket alkalmaztunk, amelyeknek a segítségével vizsgáltuk a kitöltők ismereteit a térségre jellemző, különböző légszennyező tényezők egészségkárosító voltára vonatkozóan. Az anonim kérdőív elején néhány demográfiai adatot (nem, életkor, iskolai végzettség) kértünk a kitöltóktől. Ezt követően azt vizsgáltuk, mennyire ismerik az emberek a légkör természetes összetevőit, illetve az esetleges szennyezőket. Ezután azokat az ismereteket vizsgáltuk, amelyek az egészségkárosító hatásokra vonatkoztak. Végül az utolsó kérdésben megoldási lehetőségekre kerestük a választ. Mintavételi csoportunkat azok az egyének alkották (korhatár megkötése nélkül), akik a megosztott kérdőívet önkéntesen kitöltötték. A kérdőív összesen 20 kérdésből állt, melyek között voltak egyszeres és többszörös választási lehetőséget is tartalmazó kérdések. A kitöltés néhány percet vett igénybe. Kutatásunk alapjául a Google dokumentumok ingyenes kérdőívkészítő szoftverének segítségével gyüjtöttünk adatokat 2017 decembere és 2019 májusa között. A kérdőív nyilvánosan elérhető linkjét a Facebook közösségi oldalon tettük közzé olyan csoportban, amely Miskolchoz, illetve annak környezetéhez kötődik. Az adatok elemzésekor kizártuk a kiértékelésből a megkezdett, de nem végig kitöltött kérdőíveket.

\section{EREDMÉNYEK}

A kérdőív kitöltését összesen 155 önkéntes kezdte el, és csaknem az összes, 153 válaszadó fejezte be teljes mértékben, így ennyi kérdőívet vettünk figyelembe az eredmények értékelésénél. A válaszadók mindannyian nők voltak, akiknek életkora 18-56 év között változott, de 95\%-uk a 18-25 éves korcsoportba tartozott. Az önkéntesek 81\%-a középiskolai, 10\%-a felsőfokú, 9\%-a egyéb végzettséggel rendelkezik.

A kérdőív elején azt vizsgáltuk, hogy az emberek ismerik-e a légkör természetes összetevőit alkotó gázokat. Azt tapasztalatuk, hogy a válaszadók mindössze 4\%-a nem rendelkezett megfelelő információkkal a légkör természetes összetevőiről. A válaszadók nagyrészt ismerték azokat a gázokat, amelyek főként az emberi tevékenység hatására jelennek meg a légkörben nagyobb mennyiségben, és 98,5\%-ban azt válaszolták, hogy az emberi tevékenység miatt megnövekedett mennyiségben jelen lévő gázok káros hatással lehetnek az emberi egészségre.

Több kérdés vonatkozott arra, hogy ismerik-e a válaszadók a savas eső fogalmát, és tisztában vannak-e azzal, hogy a savas eső közvetlenül, illetve közvetve hatással van mind a környezetünk, mind az emberi egészségre. Az emberek 87,5\%-a véli úgy, hogy a savas eső is hathat az emberi egészségre. 
Egy többszörös választást lehetővé tevő kérdésben azt vizsgáltuk, milyen arányban tartották felelősnek ezeket a gázokat az üvegházhatás kialakulásában. Elsősorban a szén-dioxidot (68,2\%), valamint a metánt $(56,5 \%)$ tették felelőssé az üvegházhatás kialakulásáért, harmadik leggyakoribb kiváltó okként (39,0\%) a halogénezett szénhidrogéneket jelölték meg, a vízgőzt viszont csak mindössze 18,8\%-uk tartotta fontosnak tényezőnek ebben a folyamatban. A válaszadók 75,5\%-a gondolta úgy, hogy Magyarországon is észlelhető az ózonréteg elvékonyodásának hatása, és túlnyomó többségük $(95,5 \%)$ tisztában volt azzal, hogy az ózonréteg elvékonyodása közvetlen hatással van az emberi szervezetre, és pl. bőrrákos elváltozáshoz vezethet a megnövekedett UV sugárzás.

A következő kérdéscsoportban azt tanulmányoztuk, mennyire közismert a szmog fogalma, és milyen gyakorinak tartják ezt az emberek, illetve milyen egészségügyi problémák kialakulását kapcsolják a szmog megjelenéséhez. A válaszadók 42,2\%-a gondolja úgy, hogy a szmog csak a nagyvárosokra jellemző, míg a 57,8\%-a lehetségesnek tartja, hogy a szmog kisebb településeken is kialakulhat. Egy többszörös választásos kérdésben az emberek nagyrészt a levegő szállóportartalmát (84,4\%) jelölték meg a szmog fő kiváltó okaként. A különböző gázok közül a szén-monoxidot gondolták legtöbben $(59,7 \%)$ a szmog kialakulásában fontos résztvevőnek. Az emberek mindössze 34,5\%-a gondolja úgy, hogy teljesen komolyan kell venni a szmogriadókat, mivel közvetlen kockázatot jelenthet az egészségre szmogos időszakban hosszabb ideig a szabadban tartózkodni.

A válaszadók nagyrészt légzőszervi megbetegedéseket (asztma, tüdőrák, tüdőgyulladás) jelöltek meg mint lehetséges szmog-kiváltotta megbetegedések, illetve kisebb arányban a keringési problémákat és a nemzőképesség csökkenést gondolták olyan betegségcsoportnak, melyben szerepet játszhat a levegő minősége. [1. ábra]

Arra vonatkozóan, hogy mennyire veszik komolyan a szmogriadókat, a válaszadók mindössze 35,1\%- a gondolja megfontolandónak ezeket a figyelmeztetéseket, de a többség (64,3\%), még, ha elgondolkodtatónak is találja a helyzetet, nem tarja megoldhatónak, hogy például otthon maradjon ilyen esetben.

1. ábra: A válaszadók véleménye szerint a szmog hatására leginkább kialakuló betegségek

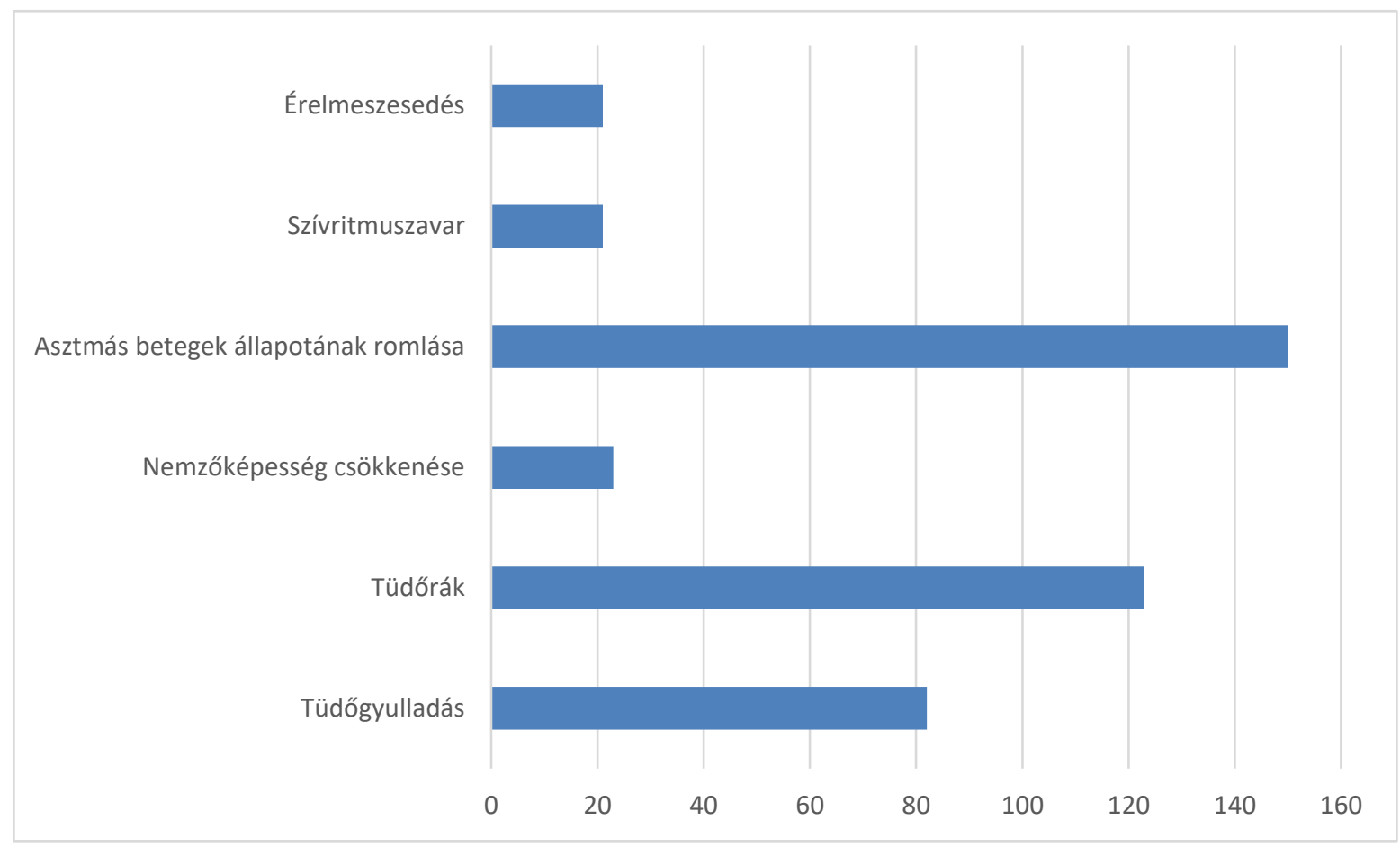

Forrás: saját szerkesztés 


\section{MEGBESZÉLÉS}

A kérdőívben kapott válaszok kiértékelése alapján elmondható, hogy a régióban élő emberek a legtöbb területen tájékozottak, és fontosnak tartják a levegőszennyezés kérdését, ellentétben az Európai Unió által végzett felmérés magyarországi adataival, ahogyan azt a bevezetésben bemutattuk. ${ }^{22}$ Megállapítható, hogy a válaszadók többsége tisztában van a levegő szennyezését főként kiváltó tényezőkkel. Csak néhány esetben mondható el, hogy nem rendelkeznek elég alapos ismeretekkel, például nem mindenki számára közismert, hogy a légkört természetes állapotában közel 78\%-ban nitrogén alkotja, és ehhez képest az ún. légszenynyező gázok csak kis mennyiségben vannak jelen. Ezzel szemben pl. az üvegházhatás kialakulásért felelős gázok vagy a szmog létrejöttében szerepet játszó tényezők esetében nagyon alapos ismeretekkel rendelkeztek a válaszadók. Az ilyen jellegú kérdésekre több olyan értékelést találtunk, amelyeket 10-16 év gyermekeknél végeztek, így az összehasonlítás nem célszerű a felnőttek körében végzett felméréssel. Az Európai Unió által a témában készített nemzetközi felmérés - melyben 29 ország vett részt - vizsgálja, hogy az emberek mennyire tartják felelősnek a levegőszennyezést a különböző megbetegedésekért. $^{22}$

Nem égetünk el fútési szezonban minden éghető anyagot.

Fútéskorszerűsítési pályázatok kritériumi listájának bővítése nem csak a városokban.

Szmogmaszkot használunk.

Csökkentjük a fosszilis tüzelőanyagok használatát.

Nem égetünk avart.

Nem használjuk a gépjármúvünket.

Nem sportolunk a szabadban (pl. kerékpározás, futás).

Csökkentjük a szabadban tartózkodás idejét.

Nem szellőztetünk.
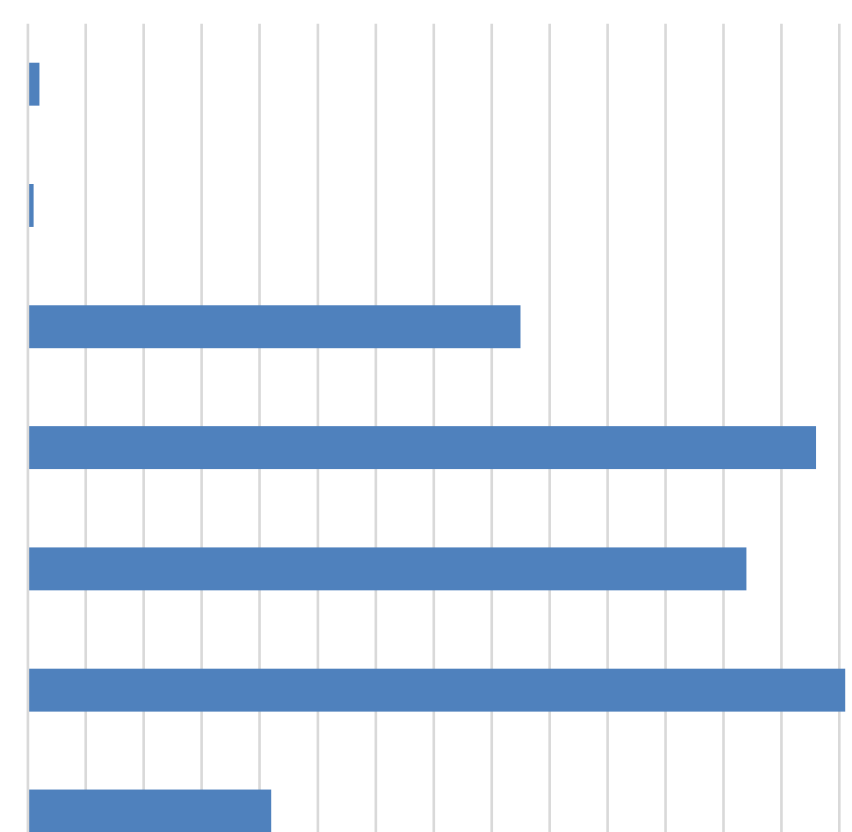

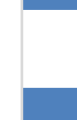
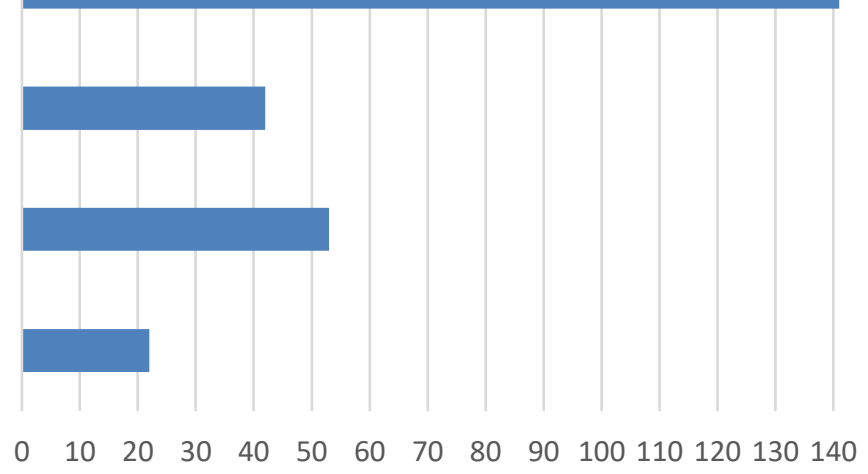

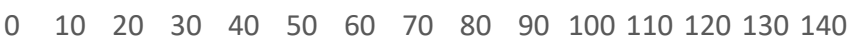

Forrás: saját szerkesztés 
Az európai országok lakói 90\%-ban tartották felelősnek a levegőszennyezést a különböző légzőszervi megbetegedésekért - különösen az asztma esetében -, amely valamivel alacsonyabb értéket mutat a válaszadóink körében (78\%), de szintén ezt gondolják a legfőbb egészségi kockázatnak. Azt a lehetőséget, hogy a kardiovaszkuláris megbetegedésekben komoly szerepet játszhatnak a levegó szennyező anyagai, az európai országokban átlagban 89\%-ban, míg az általunk megkérdezettek ezt mindössze 27,4\%-ban tartják valószínúnek. A minta szereplői tisztában vannak azzal, hogy főleg a fosszilis tüzelőanyagokkal fútés és a forgalom nagymértékű megnövekedése már a kisebb településeken is érezteti a hatását, főleg a téli időszakban. A megkérdezett személyek fontosnak tartják a személyes felelősség kérdését is. A szmog csökkentésére a 2. ábran láthatók a legtöbb szavazatot kapott megoldások.

\section{KÖVETKEZETÉSEK}

A kérdőívet kitöltők válaszai alapján megállapítható, hogy a válaszadók többsége tájékozott a levegőszennyezés kérdésében, ennek ellenére hasznos lehet felvilágosító előadássorozat szervezése az esetleges félinformációk és az információhiányok javítása céljából. Fontos lenne már ebbe a programba a középiskolásokat és egyetemistákat is bevonni, adott esetben akár projektfeladatok segítségével, míg a felnőtt korosztálynál frontális jellegű tudománynépszerűsítő előadás célszerübbnek tűnik, mely megvalósításában például a művelődési házak vagy könyvtárak bevonása jelenthetne segítséget. Ilyen kezdeményezés segíthet abban, hogy az emberek egészségtudatosabban élhessenek, és több információval rendelkezzenek arra vonatkozóan, hogy mely tényezők fenyegetik leginkább egészségüket például a levegőszennyezéssel kapcsolatban. Segithetne abban is, hogy az emberek tisztában legyenek azzal, mit tehetnek ők maguk annak érdekében, hogy mind a saját közvetlen környezetükben, mind a környező nagyobb területeken segíthessék a levegő szennyezésének korlátozását, és ez által a saját és gyermekeik, unokáik egészségét megóvhassák a levegőszennyezés káros hatásaitól.

\section{KÖSZÖNETNYILVÁNITÁS}

Köszönetet mondunk mindazoknak, akik a kérdőív önkéntes kitöltésével segítették munkánkat.

A cikkben ismertetett kutatómunka az EFOP-3.6.116-00011 jelú „Fiatalodó és Megújuló Egyetem Innovatív Tudásváros - a Miskolci Egyetem intelligens szakosodást szolgáló intézményi fejlesztése" projekt részeként - a Széchenyi 2020 keretében az Európai Unió támogatásával, az Európai Szociális Alap társfinanszírozásával valósul meg.

\section{HIVATKOZÁSOK}

\footnotetext{
${ }^{1}$ Kampa M, Castanas E. Human health effects of air pollution. Environ. Poll. 2008;151(2):362-367. doi: 10.1016/j.envpol.2007.06.012

${ }^{2}$ http://globalproblems.nyf.hu/a-levego/a-levegot-szennyezo-anyagok (Elérve: 2019. 09. 12.)

3 https://www.who.int/phe/news/clean-air-for-health/en (Elérve: 2019. 09. 15.)

${ }^{4}$ https://www.who.int/news-room/fact-sheets/detail/ambient-(outdoor)-air-quality-and-health (Elérve: 2019. 09. 14.)

${ }^{5}$ Anderson JO, Thundiyil JG, Stolbach A. Clearing the air: a review of the effects of particulate matter air pollution on human health. J Med Toxicol. 2012;(2):166-75. doi: 10.1007/s13181-011-0203-1

${ }^{6}$ Riediker M, Cascio WE, Griggs TR, et al. Particulate matter exposure in cars is associated with cardiovascular effects in healthy young men. Am J Resp Crit Care 2004;169(8):934-940. doi: 10.1164/rccm.200310-14630C

${ }^{7}$ Riediker M, Devlin RB, Griggs TR, et al. Cardiovascular effects in patrol officers are associated with fine particulate matter from brake wear and engine emissions. Part Fibre Toxicol. 2004;1(1):2. doi: 10.1186/1743-8977-1-2
} 
${ }^{8}$ Tsai D-H, Amyai N, Marques-Vidal P, et al. Effects of particulate matter on inflammatorymarkers in the general adult population. Part Fibre Toxicol. 2012;9(24) http://www.particleandfibretoxicology.com/content/9/1/24 (Elérve: 2019. 09. 22.)

${ }^{9}$ Uzu G, Sauvain J-J, Baeza-Squiban A, et al. In vitro assessment of the pulmonary toxicity and gastric availability of leadrich particles from a lead recycling plant. Environ. Sci. Technol. 2011;45(18):7611-7950. doi: 10.1021/es200374c

${ }^{10}$ Anderson TR, Hawkins E, Jones PD. $\mathrm{CO}_{2}$, the green house effect and global warming: from the pioneering work of Arrhenius and Callendar to today's Earth System Models. Endeavour, 2016;40(3):178-187.

doi: 10.1016/j.endeavour.2016.07.002

${ }^{11}$ Ramanathan V, Feng Y. Air pollution, greenhouse gases and climate change: Global and regional perspectives.

Atmos Environ. 2009;43(1):37-50. doi: 10.1016/j.atmosenv.2008.09.063

12 Strefler J, Luderer G, Kriegler E, et al. Can air pollutant controls change global warming? Environ Sci Pol.

2014;41:33-43. doi: 10.1016/j.envsci.2014.04.009

${ }^{13}$ Hajat S, Vardoulakis S, Heaviside C, et al. Climate change effects on human health:projections of temperature-related mortality for the UK during the 2020s, 2050s and 2080s. J Epidemiol Community Health. 2014;68(7):641-8.

doi: 10.1136/jech-2013-202449

${ }^{14}$ McMichael AJ Globalization, climate change, and human health. N Engl J Med. 2013; 368:1335-43.

doi: 10.1056/NEJMra1109341

15 Burns DA, Aherne J, Gay DA, et al. Acid rain and its environmental effects: Recent scientific advances. Atmos.

Environ. 2016;146:1-4. doi: 10.1016/j.atmosenv.2016.10.019

${ }^{16}$ Brusseau ML, Matthias AD, Comrie AC, et al. Atmospheric pollution. In: Brusseau ML,. Pepper IL, Gerba Ch (editors). Environmental and pollution science (third edition). Academic Press,USA, 2019. pp 293-309.

doi: 10.1016/B978-0-12-814719-1.00017-3

17 https://www.who.int/phe/news/clean-air-for-health/en/ (Elérve: 2019. 09. 20.)

18 Slovic AD, Aparecida de Oliveira M, Biehl J, et al. How can urban policies improve air quality and help mitigate global climate change: a Systematic mapping review. J Urban Health. 2016;93(1):73-95. doi: 10.1007/s11524-015-0007-8

${ }^{19}$ Sheweka S, Magdy N The living walls as an approach for a healthy urban environment. Energy Procedia.

2011;6: 592-599. doi: 10.1016/j.egypro.2011.05.068

20 https://zeosz.hu (Elérve: 2019. 09. 21.)

${ }^{21} \mathrm{http}: / / w w w . l e g s z e n n y e z e s . h u(E l e ́ r v e: ~ 2020.01 .17$.

${ }^{22}$ https://ec.europa.eu/commfrontoffice/publicopinion/index.cfm/Survey/getSurveyDetail/instruments/SPECIAL/surveyKy/2239 (Elérve: 2020. 01. 17.)

${ }^{23}$ Pluhar Zs F, Piko B F, Kovacs Sz, et al. „Air pollution is bad for my health”: Hungarian children's knowledge of the role of environment in health and disease Health Place. 2009;15: 239-246. doi: 10.1016/j.healthplace.2008.05.005

${ }^{24}$ Pluhar Zs F, Piko B F, Uzzoli A, et al. Representations of the relationship among physical activity, health andperceived living environment in Hungarian urban children's images. Landscape Urban Plan. 2010;95:151-160.

doi: 10.1016/j.landurbplan.2009.12.012

${ }^{25}$ Myers G, Boyes E, Stanisstreet, M. School students'ideas about air pollution: Knowledge and attitudes. Res Sci Techn Edu. 2004;22(2): 133-152. doi: 10.1080/0263514042000290868

${ }^{26}$ Skamp K, Boyes E, Stanisstreet, M. Students' ideas and attitudes about air quality. Res Sci Edu. 2004;34:313-342.

${ }^{27}$ Boyes E, Myers G, Skamp, K. et al. Air quality: a comparison of students' conceptions and attitudes across the continents. Compare 2007;37(4):425-445. 